\title{
The Relationship Between Entrepreneurial Self-Efficacy, Entrepreneurial Curiosity and Innovative Behavior on Entrepreneur Students
}

\author{
Unika Prihatsanti
}

Faculty of Psychology, Diponegoro University unik0206@gmail.com

\begin{abstract}
Innovative behavior is the behavior of creating and combining something new, either in the form of a product or service Entrepreneurial curiosity is a positive emotional/motivational system oriented toward investigation in the entrepreneurial framework to learn tasks related to entrepreneurship and incorporate new experiences in order to improve business. Entrepreneurial selfefficacy is an individual's belief in the ability to perform at the various requirements necessary to pursue new business opportunities This study aims to prove the relationship between the three variables. The subject of research is 116 college students who are starting a new business, with purposive sampling technique. Data collection of innovative behavior scale (33 item, $\alpha=.91)$. Entrepreneurial self-efficacy (23 item, $\alpha=.87)$, and the entrepreneurial curiosity scale consists of 11 items $(\alpha=.73)$. The regressior analysis shows a significant positive correlation between these three variables.
\end{abstract}

Keyword: Entrepreneurial self-efficacy, entrepreneurial curiosity, innovative behavior, college student.

\section{INTRODUCTION}

Unemployment in Indonesia was recorded in February 2017 of 7.005 million people. (BPS, 2017). Higher education became one of the highest levels of education, contributing $12.2 \%$ of the total unemployment in Indonesia. These data that college graduates do not guarantee someone to get a job. But it can actually be a capital for graduates to create their own jobs. As a means of increasing the number of entrepreneurs in Indonesia the government has launched a national entrepreneurship movement (GKN) since 2013. GKN is a movement to grow from the bottom so that it has a strong foundation to develop. According to the Ministry of Cooperatives Small and Medium Enterprises ( Menkop \& UKM), the ratio of entrepreneurs in Indonesia in 2013/2014 still $1.67 \%$. Now, based on BPS the data has risen to $3.1 \%$. Thus, the level of entrepreneurship in Indonesia has exceeded $2 \%$ of the population, as a minimum requirement of a society will prosper. This ratio is lower than other countries such as Malaysia 5\%, China $10 \%$, Singapore $7 \%$, Japan $11 \%$, and US $12 \%$ (Dekop, 2017).

The universities also take the role to instill entrepreneurial spirit and entrepreneurship, including the establishment of campus entrepreneurship center (BSI Entrepreneurship Center, ITB Business Incubator Center, Community Entrepreneur Program at UGM and others), entrepreneurship priority by making entrepreneurship courses become an important thing to be given to students, entrepreneurship program development (PMW), Mandiri entrepreneurship program for students, developing entrepreneurship curriculum, cooperating with business world, and so forth. Various programs are prepared for students to be ready to create jobs and not only as a job seeker. The growing entrepreneurship among students demands that they become more creative and innovative, and independently start a new business that must compete with other business actors who have already developed.

Salaman and Storey (Helmi, 2011) stated that innovation to be one of the outstanding characters in entrepreneurship and innovation is seen as a key factor for the sustainability and competitiveness of a country or organization. Wess \& Farr (Ancok, 2009) defines innovative behavior as an intention to create, introduce, and apply new ideas within groups and organizations, aimed at optimizing group and organizational performance. In the context of entrepreneurship, an innovative behavior is a behavior in create and combine something new, whether in the form of products or services that can provide social and economic value added. Such behavior consists of generating ideas, discussing ideas, and realizing ideas in the form of products or services (Helmi, 2011).

According to Axtell (Helmi, 2011), innovation takes place within three levels of individuals, groups, and organizations. Individual level innovation is called innovative behavior. Robinson, Stimpson, Huefner, \& Hunt (1991) stated that innovation can be used to predict entrepreneurship. Helmi (2011) mentioned that factors influencing the innovative behavior of UGM students who are entrepreneurs are taking risks, self-motivation, knowledge, finance, mentors, and public trust. Firmansyah \& Bachtiar (2016) in his research found innovative behavior related to small business success.

Increasing competition in the entrepreneurial world needed individuals who are ready to compete and have psychological capital. Psychological capital is a positive individual psychological condition that develops and one of them is characterized by having confidence in the ability of self in taking and giving enough effort to succeed in doing a challenging task or so-called self-efficacy (Luthans \&Youssef, 2007). Self-efficacy is defined as a belief in the ability to organize and display the actions required to produce a certain skill (Bandura, 1997). De Noble, et al (1999) described a more specific concept of self-efficacy 
associated with the entrepreneurial activity by defining the concept of entrepreneurial self-efficacy. Entrepreneurial self-efficacy is further defined as individual beliefs related to the ability to perform on the various requirements required to pursue new business opportunities. Drnovsek, Wicent, \& Cardon (2009) added that entrepreneurial self-efficacy acts during the phase of the process of starting a new business that is being developed.

Openness to experience is one of the important things for a person to start a new business. Mc Crae states that highly disclosed individuals are more tolerant of uncertainty, curiosity, innovative and imaginative (Jeraj, et al, 2015). The entrepreneurial curiosity is a positive emotional or motivational system oriented to the investigation of the entrepreneurial framework, to learn entrepreneurial tasks and to combine new experiences in order to improve business (Jeraj, 2012; Jeraj and Antončič, 2013). The curiosity of the entrepreneur is the emotional state of an aroused businessman who tends to happen after being confronted with novelty, complexity or ambiguous stimuli to find new opportunities and expand their business.

This study aims to prove the relationship of entrepreneurial self-efficacy, entrepreneurial curiosity, and innovative behavior

\section{METHOD}

Participant of this research is 116 students active in Undip, Semarang, Indonesia who have the new business at least 1 year and has entrepreneurial knowledge through entrepreneurship courses as well as entrepreneurial knowledge gained because joining the creativity program of entrepreneurship students (PKM-K). They are 27 men $(23.3 \%)$ and 80 women $(76.7 \%)$ who are $17-22$ years old. Participants were recruited through purposive sampling (Sugiono, 2005).

The research data used a modified scale, namely innovative behavior scale (33 items, $\alpha=.91$ ) based on Tiffani (2017), Entrepreneurial self-efficacy (23 items, $\alpha=.87$ ), based on Ratnaningsih, Prihatsanti \& Prasetyo (2017 ), and modification of the entrepreneurial curiosity scale consists of 11 items $(\alpha$ $=.73$ ) based on Jeraj \& Antoncic (2013).

Data were analyzed using multiple regression analysis to explain the relationship between variables and the effective contribution of entrepreneurial selfefficacy and entrepreneurial curiosity to innovative behavior. According Sugiono (2005) regression analysis is one of the measurement techniques to correlate two or more variables.

\section{RESULT \& DISCUSSION}

Table 1. Correlation Between Entrepreneurial Self-Efficacy and Entrepreneurial Curiosity to Innovative Behavior,

\begin{tabular}{|c|c|c|}
\hline Variable & $\begin{array}{l}\text { Correlation } \\
(r)\end{array}$ & Contribution \\
\hline $\begin{array}{l}\text { Entrepreneurial } \\
\text { Self-Efficacy } \\
\& \\
\text { entrepreneurial } \\
\text { curiosity }\end{array}$ & $.531^{*}$ & $28.3 \%$ \\
\hline $\begin{array}{l}\text { Entrepreneurial } \\
\text { Self-Efficacy }\end{array}$ & $.502^{*}$ & $25.2 \%$ \\
\hline $\begin{array}{l}\text { Entrepreneurial } \\
\text { Curiosity }\end{array}$ & $.418^{*}$ & $3.1 \%$ \\
\hline
\end{tabular}

Based on data analysis, in Table 1 shows that the entrepreneurial self-efficacy and entrepreneurial curiosity has a positive and significant correlation with the innovative behavior of the students' entrepreneurship, with $r=.531(\mathrm{p}<.001)$. These results suggest that entrepreneurial self-efficacy and entrepreneurial curiosity have role in the emergence of innovative behavior. Entrepreneurial self-efficacy contributes $25.2 \%$ to innovative behavior. The study of Saepudin, Adiwinartra, Ilfiandra \& Sukarya (2015) found that self-efficacy has a significant influence on entrepreneurship behavior.

Stajkovic and Luthans (Luthans, Youssef \& Avolio, 2007) claim self-efficacy affects a person in thinking, feeling, encouraging and behaving. Innovative behavior creates opportunities to grow the business by making new breakthroughs. Ratnaningsih, Prihatsanti, \&Prasetyo (2016) mentioned that selfefficacy role in innovative behavior employees manufacturing company. Individuals' confidence in their own ability is important for enabling individuals to think and produce new ideas (idea generation). Such individuals are also confident in expressing their ideas and courageous in their plays of ideas. Thus high entrepreneurial self-efficacy will predict the high behavior of innovative students who entrepreneurship.

Entrepreneur curiosity contributes $3.1 \%$ to students' innovative behavior. In line with the results of the study of Peljko, Jeraj, Savoiu, Maric (2016) who found that entrepreneurial curiosity is associated with innovative behavior in entrepreneurs in Slovenia and USA. Jeraj's research, et al (2015) mentioned that entrepreneurial curiosity is positively related to company's growth.

DeJong (2007) described the innovative behavior as one's behavior that leads to the emergence and introduction of new ideas, processes, products, or procedures through efforts to deliver useful new results. DeJong \& De Hartog (2008) described innovative behavior consisting of four dimensions: opportunity exploration, idea generation, championing, and application. In this study, the students' innovative behavior is in the medium category of $75.9 \%$ and $24.1 \%$ in the high category. The mean comparison result indicates that the empirical average $(x=93.84)$ 
higher than hypothetical average $(\mu=82.5)$ indicates that the students' innovative behavior on the high category. This category shows that students can see opportunities; able to generate new and creative ideas using existing resources so that they will be able to see solutions to different ways of thinking; seeking support behavior and building coalitions with others; and they can apply new ideas.

Table 2. Correlation between Entrepreneurial Self-Efficacy Dimensions and Innovative Behavior

\begin{tabular}{lcc}
\hline \multicolumn{1}{c}{ Dimension of } & \multicolumn{2}{c}{$\begin{array}{c}\text { Entrepreneurial } \\
\text { Entrepreneurial Self- }\end{array}$} \\
$\begin{array}{c}\text { Efficacy } \\
\text { Self-Efficacy }\end{array}$ \\
$\begin{array}{l}\text { Developing new product \& } \\
\text { market opportunities }\end{array}$ & 456 & $000^{*}$ \\
$\begin{array}{l}\text { (DPM) innovative } \\
\text { Building on investor } \\
\text { environment (BIE) }\end{array}$ & 252 & $006^{*}$ \\
$\begin{array}{l}\text { Initiating purpose } \\
\text { relationship (IIR) }\end{array}$ & 300 & $000^{*}$ \\
$\begin{array}{l}\text { Defining core } \\
\text { (DCP) }\end{array}$ & 328 & $000^{*}$ \\
$\begin{array}{l}\text { Coping with unexpected } \\
\text { challenges (CUC) } \\
\text { Developing critical human } \\
\text { resources (CHR) }\end{array}$ & 275 & $003^{*}$ \\
\hline
\end{tabular}

Table 2 shows a positive and significant correlation between the dimensions of entrepreneurial selfefficacy and innovative behavior. Developing new product and market opportunities involve the belief of being able to create new products and to find opportunities, to have a solid foundation for starting a business. Building on innovative environment involves a person's beliefs to encourage others or his team to try new ideas, or to take innovative action. Initiating an investor relationship involves a person's beliefs in being able to find sources of funding for their business. Defining core purpose involves a person's confidence to be able to clarify vision and maintain vision, and clarify to teams and investors. Coping with unexpected challenges involves a person's beliefs in being able to tolerate ambiguity and uncertainty in entrepreneurship. While developing critical human resources involves a person's belief in being able to recruit and retain important and talented people to become members of the business.

\section{CONCLUSION}

Based on the results of the study, it can be concluded that there is a significant positive relationship between entrepreneurial self-efficacy, entrepreneurial curiosity, and innovative behavior in entrepreneurial students. $(\mathrm{r}=.531, \mathrm{p}=.000)$. Together, the increase in entrepreneurial self-efficacy and entrepreneurial curiosity will be able to increase or foster student innovative behavior. Both variables contribute $28.3 \%$ to innovative behavior. This study has limitations related to participant research, type of business and entrepreneurial knowledge that varies so that it may not be generalizable to a wider population with different types of business. Similarly, the measuring tool of entrepreneurial curiosity with the number of items may be less able to represent the right measurement. Subsequent research needs to explore participant and the selection of measurement tools more suitable, in the wider context.

\section{REFERENCE}

Ancok, D. (2009). Kepemimpinan \& inovasi. Yogyakarta: Fakultas Psikologi UGM

Bandura. A. (1997). Self efficacy. the exercise of control. New York: W.H. Freeman and company.

Badan Pusat Statistik. (2017). Pengangguran terbuka menurut pendidikan tertinggi yang ditamatkan 2007 - 2017. Retrieved from https://www.bps.go.id/linkTabelStatis/view/id/9 72.

De Noble. A.. Jung. D.. and Ehrlich. S. (1999). Entrepreneurial Self Efficacy: The Development of a Measure and Its Relationship to Entrepreneurial Action. Frontiers of Entrepreneurship Research. Wellesley. MA: Babson College. 73-87.

De Jong, J.P.J. (2007). Individual innovation: The connection betweenleadership andemployees' innovative work behavior. Tesis. Amsterdam: EIM Business and Policy Research.

De Jong, J.P.J., \&Den Hartog, D.N. (2008). Innovative work behavior: measurement and validation. European Journal of Innovation Management, 19, 23-36. doi:10.1111/j.14678691.2010.00547.x.

Dekop. (2017). Ratio wirausaha Indonesia naik jadi 3,1 persen. Retreived from http://www.depkop.go.id/content/read/ratiowirausaha-indonesia-naik-jadi-31-persen/.

Drnovsek, M., Wincent, J., Cardon, M.S. (2009). Entrepreneurial self-efficacy and business startup: developing a multi-dimensional definition. International Journal of Entrepreneurial Behaviour \& Research Vol. 16 No. 4, 2010 pp. 329-348.

Firmansyah, M.A., Bachtiar, M. (2016). Hubungan antara perilaku inovatif wirausaha dengan keberhasilan usaha kecil. Jurnal Psikologi Sosial, 23, 17-27.

Helmi, A.F. (2011). Model determinan perilaku inovatif mahasiswa yang berwirausaha. Jurnal Psikologi. Vol 28 (2), 134-136.

Jeraj, M., Marič, M., Todorović, I., Čudanov, M. and Komazec, S., 2015. The Role of Openness and Entrepreneurial Curiosity in Company's Growth. Amfiteatru Economic, 17(38), pp. .371389.

Jeraj,M \& Antoncic, B. (2013) A Conceptualization of Entrepreneurial Curiosity and Construct Development: A Multi-Country Empirical Validation, Creativity Research Journal, 25:4, 426-435, DOI: 10.1080/10400419.2013.843350.

Kuswara, H. (2012). Strategi perguruan tinggi mewujudkan entrepreneurial campus. Retreived from http://www.dikti.go.id/strategi-perguruantinggi-mewujudkan-entrepreneurial-campus/.

Luthans, F., Youssef, C. M., \& Avolio, B. J. (2007). Psychological capital: developing the human competitive edge. New York, NY: Oxford University.

Peljko, Ž., Jeraj,M., Săvoiu, G., Marič, M. (2016). An 
Empirical Study of the Relationship between Entrepreneurial Curiosity and Innovativeness. Organizacija, Volume 49 Research Papers Number 3, August 2016. DOI: 10.1515/orga2016-0016.

Ratnaningsih, I.Z., Prihatsanti, U., Prasetyo, A.R. (2017).

Meningkatkan Entrepreneurial Self Efficacy Mahasiswa dengan Appreciative Inquiry Plus dan Active learning. Asian Journal of
Entrepreneurship and Family Business. Vol. 1, No. 1. http://perwiraindonesia.com/ajefb/

index.php/jurnalAJEFB/article/view/13.

Sugiyono (2005). Statistika untuk penelitian (Statistics for research). Bandung. Alfabeta.

Tiffani, R. (2017). Hubungan antara efikasi diri berwirausaha dengan perilaku inovatif pada anggota himpunan pengusaha muda Indonesia (HIPMI) Perguruan Tinggi Semarang. Skripsi. Fakultas Psikologi Undip: tidak diterbitkan. 